\title{
Chinese Dragon venturing into GMS teritory : Does it Makes Sense?
}

\author{
Nilanjan Banik* Khanindra Ch. Das**
}

\begin{abstract}
The notion that China is factory of the world is now changing. Factories in China are shifting their production base to neighboring Asia, primarily because of higher input costs in China, a volatile Chinese exchange rate, and protectionist measures targeted against Chinese exports. In this paper, we examine the location substitution effect for China: Chinese firms are exporting primary, intermediate and machinery items, meant for producing final output in the Greater Mekong Subregion (GMS). Results suggest that GMS countries are exporting finished items to China, that are increasingly getting manufactured using primary and intermediate inputs imported from China.
\end{abstract}

Key Words : Trade, Location Substitution Effect,China, GMS

JEL Classification : F14, F15, F21

* Professor, Institute for Financial Management and Research (IFMR), Chennai. Corresponding author. All comments to nilbanik@gmail.com.

** Research Scholar, Institute for Financial Management and Research (IFMR), Chennai. 


\section{Introduction}

China is the second largest economy in the world after the US. Trade account for around seventy percent of China's gross domestic product (GDP), making it an important component of national income. The reason for success, especially in trade, has to do with the fact that China imports primary and intermediate goods from neighboring Asia, assembles them in the factories of coastal provinces, such as Guangdong, and transport these assembled products through its port at Hong Kong and Shenzen, to destinations such as in Europe, and the USA. Most of these intermediate inputs are manufactured in Thailand, Myanmar, and Viet Nam, which are finally used for producing Chinese made electronic items. China's trade pattern, which is, maintaining trade surplus with the EU and the US, whereas, maintaining trade deficits with Japan, Taiwan, South Korea, and the ASEAN supports the proposition that China is "factory of the world." In fact, studies have shown there is an increase in foreign content for Chinese exports. Assembling, and processing of imported inputs meant for re-exports account for about half of China's foreign trade (Hummels et al., 2001; Koopman et al., 2008). Higher foreign content of its exports is due to vertical intra-industry tradel) which has grown manifold in China, and possibly may have been responsible for its diverse exports base, from electronics and machinery to textile and apparel (Fukao et al., 2003; Ando, 2006; Gaulier et al., 2007).

\section{Table 1.}

China's Merchandize Trade (in 100million US \$)

\begin{tabular}{ccccccc}
\hline \multirow{2}{*}{$\begin{array}{c}\text { Country or } \\
\text { Region }\end{array}$} & $\begin{array}{c}\text { Export } \\
\text { Value }\end{array}$ & $\begin{array}{c}\text { Import } \\
\text { Value }\end{array}$ & $\begin{array}{c}\text { Trade } \\
\text { Surplus }\end{array}$ & $\begin{array}{c}\text { Export } \\
\text { Value }\end{array}$ & $\begin{array}{c}\text { Import } \\
\text { Value }\end{array}$ & $\begin{array}{c}\text { Trade } \\
\text { Surplus }\end{array}$ \\
\hline Europe & 2647 & 1620 & 1026 & 3552 & 2179 & 1373 \\
USA & 2208 & 775 & 1433 & 2833 & 1021 & 1812 \\
ASEAN & 1063 & 1067 & -5 & 1382 & 1547 & -165 \\
Japan & 979 & 1309 & -330 & 1210 & 1767 & -557 \\
South Korea & 537 & 1025 & -489 & 688 & 1383 & -696 \\
\hline
\end{tabular}

Sources : Statistical Communiqué of the PRC, 2011

1) Vertical integration happens when a firm controls several steps in the production and distribution process, such as a firm having its own supply and distribution facilities. According to Ando (2006) the explosive increase in vertical intra-industry trade in East Asia is largely due to the expansion of back-and-forth transaction in vertically fragmented cross-border production process. 
However, recently this notion about China being factory of the world is changing. Factories in China are shifting their production base to neighboring Asia, primarily because of higher input costs in China, a volatile Chinese exchange rate, Chinese exports being increasingly targeted by its major trading partners, and a fall in price-competitiveness in producing goods in mainland China. Pushed by these domestic disadvantages and external restrictions, and helped by change in government policy to circumvent such problems, there has been industrial restructuring in the form of diversification of production base of some of the products to cheaper overseas destinations. This has been part of 'going global' strategy that has lead to offshore equity investments and acquisitions. Such an effect relating to the shift in production location from home country to cheaper overseas locations (also known as location substitution effect), is possible for firms in China because their method of production - particularly the low-and-medium technology products that can be easily replicated in other developing countries. If China were to shift its factories outside China, we would expect that China is exporting primary, intermediate and machinery items, to neighboring Asia, and importing finished manufactured items from them.

In this paper, we examine this hypothesis, that is, location substitution effect with respect to Chinese investment in the Greater Mekong Sub-region (GMS)2). Although Chinese companies are investing in countries around the globe, GMS is a natural choice given their geographical proximity to China, and free trade agreements that prevail between countries in the GMS and China. Results suggest that China is exporting primary and intermediate inputs (including machinery items), and in turn expanding manufacturing base in the GMS. Intermediate inputs are used for producing final manufactured items such as telephones, computers, air conditioners, refrigerators, and televisions, in Viet Nam and Thailand; whereas primary items comprising of textile and woven fabrics are used in garments manufacturing units in Cambodia, Laos, and Myanmar. For the location substitution effect hypothesis to be valid, we would expect a greater level of association between imports of primary and intermediate items from China with the exports of finished manufactured items to China, both with reference to the GMS. Our result supports this hypothesis about the existence of location substitution effect.

This aspect about examining location substitution effect has not been considered before, and this study fills this gap. Through this study we expect to complement an important aspect of new trade theory, which suggests, a way to explain vertical intra-industry trade is to look at the extent of firm-level heterogeneity. Extent of heterogeneity within any given industry affects outsourcing decision - with high

2) GMS comprises of Yunnan and Guangxi province of Peoples Republic of China (PRC), Thailand, and CLMV (Cambodia, Lao People's Democratic Republic, Myanmar, and Vietnam) countries. The GMS is a natural economic area held together by the Mekong River. 
productivity firms sourcing intermediate inputs in international markets, and multinational firms with heterogeneous productivity self-select into different host countries (Helpman, 2006; Castellani et al., 2010; Chen and Moore, 2010). Therefore, this study will also help to understand changing nature of international trade and investment linkages. The rest of the paper is organized as follows. Section 2 documents reasons for China to relocate its production base. Section 3 deals with the methodology, and data used for this study. Section 4 contains results. And, we conclude in section 5.

\section{CHINA'S COMPETITIVE DYNAMICS}

Before empirically examining the applicability of location substitution effect we discuss the factors that are motivating the Chinese firms to relocate their production base outside mainland China.

\section{Economic Crisis and the Chinese Exports}

The financial crisis since 2007 has seriously affected world trade, with some governments resorting to protectionist measures, such as antidumping and countervailing measures to protect their domestic industries. It is no surprising to see that such protectionist measures is hurting China the most, especially because during 2008 and 2009, Chinese exports value ranked highest in the world. During 2008, Chinese exports to the EU, and the US fell by 19.4 per cent, and 12.5 per cent, respectively. China's trade surplus fell from US\$298.1 billion in 2008 to US\$ 195.8 billion in 2009.

Global Trade Alert database (a database tracking number of protectionist measures imposed around the world) has indicated that as many as 659 measures have been initiated against the Chinese exports in 2009. Most of these measures (numbers of measures initiated are indicated in parenthesis) have originated from - Russia (31), Germany (18), France (16), United Kingdom (17), Spain (16), Italy (15), Netherlands (15), Sweden (13), Austria (13), Belgium (13), Finland (13), in Europe, and USA (9).

Chinese firms are looking for an alternate production base to evade such protectionist measures. Given their geographical proximity, the GMS member countries become a natural choice. Figure 1 shows when it comes to imposition of protectionist measures, the ASEAN member countries are much less hostile towards Chinese exports in comparison to the EU, and the US. 


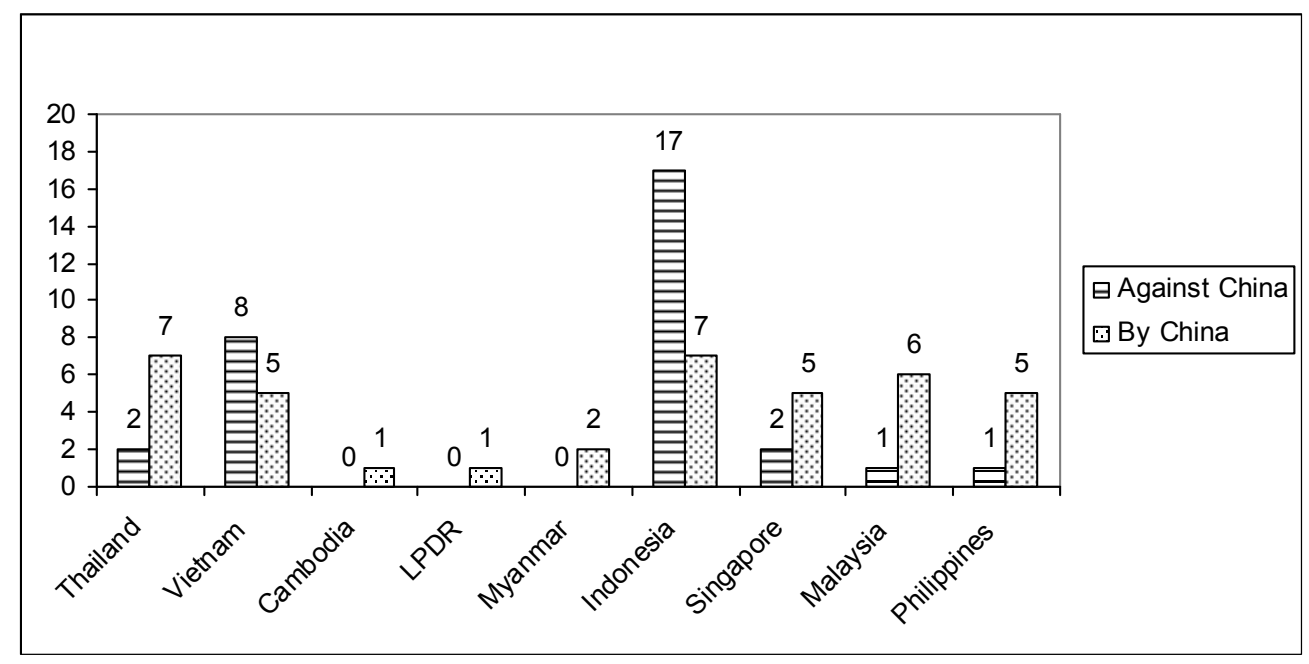

Source : Global Trade Alert, November 2010.

Figure 1.

Number of Measures against (and by) China

\section{Higher Input Cost}

The China growth story is still intact making it a favorable destination among the foreign fund managers. Last year, China has received more foreign fund - much higher than any of other 4 emerging economies in the BRICS group, comprising of Brazil, Russia, India, and South Africa. The expectation about future appreciation of Chinese renminbi also has been responsible for enhancing inflow of foreign funds. Chinese central bank has been frantically trying to keep renminbi from appreciating further by actively intervening in the foreign exchange market. Active intervention in the foreign exchange market has resulted in inflation (Zhang, 2009). In addition, wages of migrant workers, land, property rents, and power prices, have all registered an increase. Measured on a year-over-year basis, as of November 2010, labor costs have gone up by 21 per cent, and the home prices across 70 cities in China have gone up by 7.7 per cent. 2010 estimates suggest minimum annual wage rates for Cambodia, Laos, and Viet Nam are US\$ 600, US\$ 434, and between US\$ $1200-1500$, respectively. If one were to add the mandatory welfare allowances to the minimum annual wage rates, then the Chinese labor costs are at least double compared to laborers in other regions in south-east Asia (Devonshire-Ellis, 2011).

$\mathrm{Li}$ and $\mathrm{He}$ (2007) provide evidence about foreign fund entering into the real estate sector. What is worrisome is that property prices are rising despite the government having 
ownership right for land - indicating possible real estate bubble. China has also imposed stricter pollution control norms on its industries, raising the marginal cost of producing goods in China, further.

Hence, Chinese firms stand to gain by shifting production base to the neighboring south-east Asia, with a lower production cost. Also, as Chinese currency has been appreciating since 2005, and with an expectation that it will appreciate further, there is a likelihood of Chinese exports becoming costlier. Chinese firms can gain by importing raw material (as imports become cheaper when currency appreciate), and use this imported raw material to produce finished goods outside China.

\section{Access to a bigger market}

Trade and investment measures undertaken in the south-east Asian region are non-discriminatory and complementary in nature. These nations are increasingly driving down differences among each other by reducing tariffs, and other border costs. Most of the items are traded at zero tariffs among the member countries. Thailand, Laos, Cambodia, Viet Nam, and Myanmar are all part of ASEAN. As on 1 January 2010 duties on 99.65 per cent of all tariff lines under the Common Effective Preferential Tariff Scheme for the ASEAN Free Trade Area have been eliminated. For the newer ASEAN Member States Cambodia, Laos, Myanmar, and Viet Nam -98.96 per cent of total tariff lines are within the tariff of 0 to 5 per cent range. Since October 2003, China and Thailand have taken lead in implementing zero tariffs on agricultural products, covering 200 types of fruits and vegetables. China has also granted zero tariffs treatment to Cambodia (83 products), Laos (91 products), and Myanmar (87 products). Free market access for Chinese exports into this region means a larger market share for their manufacturers.

\section{Inflation, Exchange Rate Appreciation and External Price Competitiveness}

Rapid economic growth in China over the last two decades has been accompanied by a surge in foreign capital inflows both in current and capital accounts (the 'twin surpluses'), causing a massive accumulation of foreign exchange reserve (US\$ 2.65 trillion by September 2010).3) Accumulation of foreign exchange reserve has its own risks, including the cost of holding in low yielding financial assets of foreign governments. Before the

3) China's entry into WTO in 2001 has made it easy for many multinational firms to invest in China, an attractive investment destination (He and Lyles, 2008). 
global economic crisis started, China has invested a major portion of their trade surplus in US dollars and Euro-denominated assets. Values of these assets are now falling because of Federal Reserve in the US, and European Central Bank in the EU, are printing too much money. In fact, USA is investing in assets in China, and other emerging economies in Asia through Foreign Direct Investment (FDI) route, thereby exporting inflation (Banik, 2011). The EU, and the US still remain the largest investors in China. Such investment is leading to accumulation of foreign currencies, making it difficult for the Chinese monetary authority to prevent growth of 'excess liquidity'. A part of this excess liquidity is finding its way into the Chinese stock market, further accelerating inflation ( $\mathrm{Li}$ and He, 2007). In fact, for the period between 1980 and 2002, pass through effect of exchange rate translating into higher domestic price was much less in comparison to the period after 2002 (Yu, 2007).

The People Bank's of China want to curb this inflation by formulating contractionary monetary policy, raising the interest rates. The rise in interest rates in China relative to the US in recent years has accentuated the inflow of capital. The appreciation of Chinese renminbi alongside with an increase in inflation has hurt Chinese external competitiveness. Following goods market approach of determining the value of exchange rate, we define external competitiveness of any country, as the difference between domestic inflation and movement in its exchange rates. As is evident from Table 2, China's external competitiveness has faired reasonably well against many of the GMS countries until 2006 but has started to fall thereafter, especially, since 2007. For example, in 2007, Vietnam and Cambodia, have shown better external price competitiveness. In particular, in 2009, Thailand, and Cambodia, has done better relative to China in terms of price competitiveness. Starting 2000, price competitiveness is declining for China. This is going to hurt price elastic low technology intensive exports, such as leather foot ware, and apparel. In fact, share of these items has fallen in total exports (Amiti, and Freund, 2008). The fall in price competitiveness has also motivated Chinese firms to relocate their production base outside China.

Table 2.

External Competitiveness (change in price - change in nominal exchange rate)

\begin{tabular}{cccccc}
\hline Year & China & Thailand & Vietnam & Cambodia & Laos \\
\hline & 0.25 & -4.49 & -3.32 & -1.66 & 14.02 \\
2001 & 0.74 & -9.14 & -4.37 & -2.57 & -5.71 \\
2002 & -0.76 & 4.01 & 0.07 & 3.33 & -1.67 \\
2003 & 1.15 & 5.24 & 1.71 & -0.36 & 10.39 \\
2004 & 3.89 & 5.80 & 6.23 & 2.84 & 10.31
\end{tabular}




\begin{tabular}{cccccc}
\hline Year & China & Thailand & Vietnam & Cambodia & Laos \\
\hline 2005 & 2.82 & 4.55 & 7.56 & 4.45 & 6.51 \\
2006 & 4.16 & 10.45 & 6.53 & 5.88 & 11.45 \\
2007 & 9.34 & 11.16 & 7.61 & 8.82 & 10.00 \\
2008 & 14.53 & 8.89 & 21.89 & 25.05 & 16.57 \\
2009 & 0.98 & -3.77 & 2.38 & -2.76 & 2.64 \\
\hline
\end{tabular}

Note : Higher values indicate fall in competitiveness.

Source : Calculated from International Financial Statistics, International Monetary Fund.

In addition to, higher inflation rates and interest rates, the Chinese renminbi has also become more volatile. Once the longstanding peg to the US dollar was abandoned in July 2005, the renminibi-dollar exchange rate has shot-up, appreciating by about 20 percent, (Figure 2).

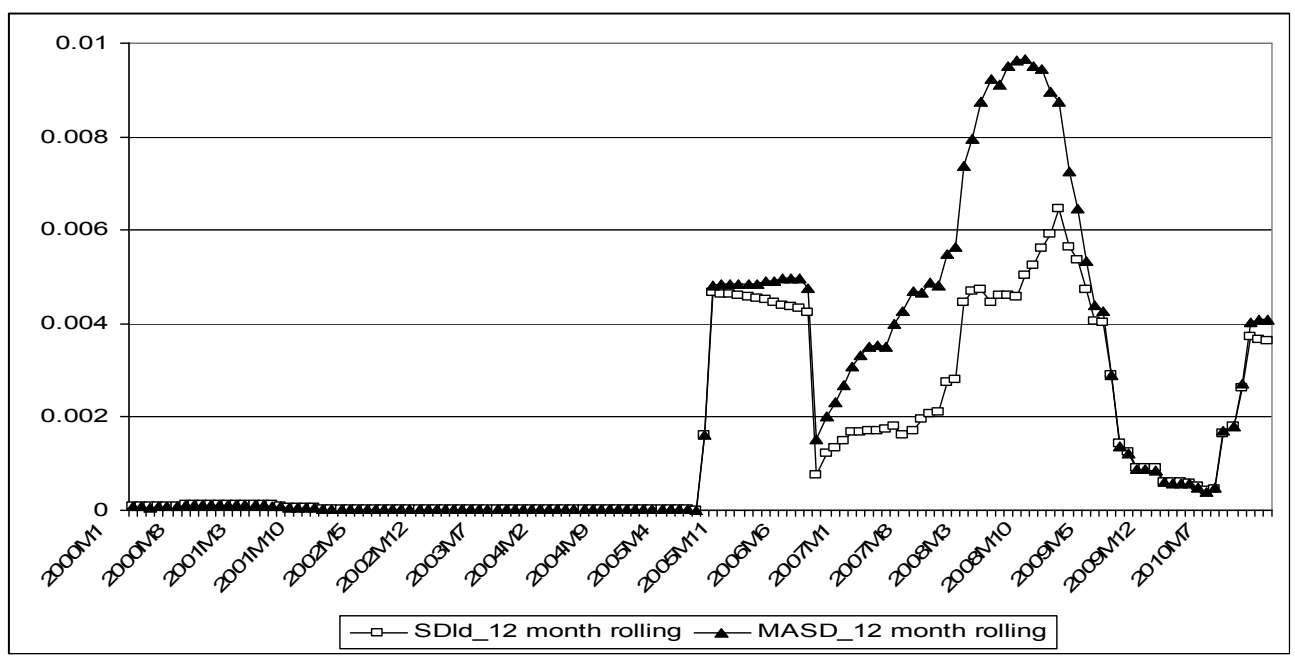

Source : Calculated from International Financial Statistics, International Monetary Fund.

Note : Volatility is calculated using (a) the standard deviation of the first difference of the log of monthly exchange rate (SDld), and (b) the moving average standard deviation (MASD) of the log of (monthly) exchange rate. Such measures have been used for studying the impact of exchange rate volatility on exports (See Tenreyro, 2007; Chit et al., 2010).

\section{Figure 2.}

\section{Volatility of RMB-dollar Exchange Rate}

Exchange rate volatility can have negative effect on international trade, directly through uncertainty and adjustment cost, and indirectly through its effect on allocation of 
resources (Côte, 1994).

\section{METHODOLOGY AND DATA}

Trade flow is usually explained using the gravity model. The original application of the Newtonian law of gravity in the field of economics goes back to the work of Tinbergen (1962), Poyhonen (1963), and Linnemann (1966), suggesting that bilateral trade between two nations is positively related to their national income, and inversely related to the distance between them.4) For this study, to examine, location substitution effect for China, we use a variant of the gravity model using two-stage least squares technique (2SLS). We use 2SLS framework to control for endogeneity, and also to capture simultaneity of two-way trade between China and the GMS. Following, Leamer and Stern (1970), and Magee (1975), we specify the exports and imports demand functions. For the purpose of our analysis, we categorize the commodities into two groups, namely, primary and intermediate exports including machinery, and final manufactured goods (See, the Appendix). For this classification, we use Standard International Trade Classification (SITC) Revision 3 at a two-digit level.

Data Source: Data on trade (both exports and imports) between China and individual countries within GMS are obtained from the United Nations COMTRADE database. Trade figures are reported in constant US dollars for each country. The data are available annually and involve trade values of 4 GMS countries, namely, Thailand, Vietnam, Cambodia, and Laos, with China.5) The time period is between 2000 and 2009. In total, we have 40 observations, involving 4 countries and 10 years data. We choose this time period because GMS initiative was undertaken starting early 2000, and there were considerable trade integration happening in this region (through tariffs reduction) during this period.

For commodity classification into primary, intermediate, and final manufactured items, we have followed the classification put forward by Lall $(1998,2000)$. Primary exports contains items falling under SITC headings 0 to 4 . Intermediate and machinery items fall under SITC headings 5, 6, 7, and 8, whereas, the final manufactured items falls under SITC headings 7 , and 8.6) To arrive at overall primary, intermediate and machinery exports, and

4) For more discussion about the theory of the gravity model, see Anderson and van Wincoop (2004).

5) Trade statistics for Myanmar are not available. Accordingly, we have to exclude Myanmar from our analysis.

6) For a detail classification, see the Appendix. SITC headings 7 and 8 , contains both final manufactured items, and intermediate and machinery items. For our analysis, machinery items are treated as an intermediate item. 
final manufactured exports, we aggregate trade values for all commodities falling under respective categories.

\section{Estimation}

We estimate the following equations:

$$
\begin{aligned}
& F X_{i c}^{t}=\alpha_{1}+\beta_{1} P I M_{i c}^{t}+\beta_{2} G D P_{c}^{t}+\epsilon_{i}^{t} \cdots \cdots(1) \\
& P I M_{i c}^{t}=\alpha_{2}+\gamma_{1} F X_{i c}^{t}+\gamma_{2} P I M_{i c}^{t-1}+\gamma_{3} G D P_{i}^{t}+\epsilon_{i}^{t} \cdots \cdots
\end{aligned}
$$

where, $F X_{i c}^{t}$ is the total value of final manufactured exports at time period $t$ from country $i$ to China ( $i=$ Thailand, Vietnam, Cambodia, and Laos);

$P I M_{i c}^{t}$ refers to primary, intermediate and machinery imports of country $i$ from China;

$G D P_{c}^{t}$ is China's GDP, and $G D P_{i}^{t}$ is $i^{t h}$ country's GDP.

$F X_{i c}^{t}$ and $P I M_{i c}^{t}$ are the endogenous variables, whereas, $G D P_{c}^{t}, G D P_{i}^{t}$, and $P I M_{i c}^{t-1}$ are the exogenous variables. As equation (1) is overidentified, we use 2SLS to derive efficient estimates. For comparison, and to capture the individual country effect, we also consider the least square dummy variable (LSDV) model. $\epsilon_{i}^{t}$ is the disturbance term. In LSDV, $\epsilon_{i}^{t}$ captures both country specific (cross sectional) and temporal effects.7) We use country specific dummies to capture individual country characteristics. As we are not randomly selecting countries within GMS, there is no necessity to undertake random effect modeling (where it is assumed we are randomly selecting sample countries from the population). ${ }^{8)}$ Also, since cross sectional element in our case is small (comprising of 5 different countries, including China), the dynamic panel approach of generalized method of moments (GMM) estimation techniques, which are expected to yield more consistent estimates in presence of large cross section, are not considered. ${ }^{9)}$ In a dynamic panel there can be an element of co-integration among exports, imports and GDP - as all of these variables tend to move in the same direction. However, Levin, Lin and Chu test confirms absence of non-stationarity, and hence co-integration in this dynamic panel framework. For each one of these variables superscript $t$ stands for time, and subscript $c$ implies China. All the variables, except for the dummies (as in the case with LSDV), are reported in log.

7) We use j-1 dummies to avoid dummy variable trap. For this analysis, Laos is treated as the base country.

8) In fact, fixed effect and random effect are going to yield similar results when all samples in the population are used for regression.

9) For more on the application of GMM techniques in the context of gravity equation see Arellano and Bond (1991) and Blundell and Bond (1998). This is a widely acknowledged that use of GMM techniques in the presence of small number of cross section element will increase the finite sample bias. 


\section{RESULTS}

Table 3.

Results of the Estimated Model for 4 GMS Countries

\begin{tabular}{|c|c|c|c|c|}
\hline Variable & $\begin{array}{c}F X_{i c}^{t} \\
(\mathrm{LSDV})\end{array}$ & $\begin{array}{c}F X_{i c}^{t} \\
(2 S L S) \\
\end{array}$ & $\begin{array}{l}P I M_{i c}^{t} \\
(\mathrm{LSDV}) \\
\end{array}$ & $\begin{array}{c}P I M_{i c}^{t} \\
(2 \mathrm{SLS}) \\
\end{array}$ \\
\hline Constant & $\begin{array}{l}-0.1231 \\
(0.2182)\end{array}$ & $\begin{array}{l}-0.0240 \\
(0.2254)\end{array}$ & $\begin{array}{c}0.2793 \\
(0.2456)\end{array}$ & $\begin{array}{c}-0.1681 \\
(0.1186)\end{array}$ \\
\hline$P I M_{i c}^{t}$ & $\begin{array}{c}0.6713^{* * * *} \\
(0.1355)\end{array}$ & $\begin{array}{c}0.7822^{* * * *} \\
(0.1455)\end{array}$ & - & - \\
\hline$F X_{i c}^{t}$ & - & - & $\begin{array}{c}0.8572 * * \\
(0.3598)\end{array}$ & $\begin{array}{l}-0.0751 \\
(0.2186)\end{array}$ \\
\hline$G D P_{c}^{t}$ & $\begin{array}{c}0.0773 \\
(0.1154)\end{array}$ & $\begin{array}{c}0.0260 \\
(0.1191)\end{array}$ & - & - \\
\hline$G D P_{i}^{t}$ & - & - & $\begin{array}{l}1.3835^{* *} \\
(0.5895)\end{array}$ & $\begin{array}{c}0.1621 \\
(0.1818)\end{array}$ \\
\hline$P I M_{i c}^{t-1}$ & - & - & $\begin{array}{c}1.0100^{* * *} \\
(0.1143)\end{array}$ & $\begin{array}{c}1.0088^{* * * *} \\
(0.1238)\end{array}$ \\
\hline Dummy Thailand & $\begin{array}{c}0.9933 * * * \\
(0.2824)\end{array}$ & - & $\begin{array}{c}-1.2308^{*} \\
(0.6494)\end{array}$ & - \\
\hline Dummy Vietnam & $\begin{array}{c}-0.4777^{*} \\
(0.2714)\end{array}$ & - & $\begin{array}{l}-0.2010 \\
(0.2314)\end{array}$ & - \\
\hline Dummy Cambodia & $\begin{array}{l}-0.0587 \\
(0.1820)\end{array}$ & - & $\begin{array}{l}-0.0519 \\
(0.0888) \\
\end{array}$ & - \\
\hline Adjusted R2 & 0.8629 & 0.8589 & 0.9695 & 0.9644 \\
\hline F Test & $19.36^{* * *}$ & $19.24 * * *$ & $80.52 * * *$ & $73.78 * * *$ \\
\hline
\end{tabular}

*** significant at $1 \%, * *$ significant at $5 \%, *$ significant at $10 \%$

Figures in the parenthesis are standard errors.

Table 3 indicates that imports of primary, intermediate and machinery items from China are related to the exports of finished manufactured items to China, both with reference to the GMS. A positive and significant $\beta_{1}, \gamma_{1}$, and $\gamma_{2}$, support the location substitution effect hypothesis. A large adjusted $R^{2}$ reveals a higher degree of association between intermediate inputs and final output. The 2SLS and the LSDV estimates suggest that final exports of GMS countries going to China are increasingly getting manufactured using primary, intermediate and machinery items imported from China. This result is validated by high correlation coefficient of 0.81 between primary, intermediate and machinery imports from China with final manufactured exports to China. Statistically, 
insignificant Chinese GDP may indicate Chinese imports from GMS is not driven by China's income but because of other factors such as procuring goods from cheaper overseas destination. In LSDV, the significant country dummies indicate the importance of GMS in China's trade.

The location substitution effect is substantiated by growing importance of GMS in China's total trade.10) Banik (2011) indicates that China is exporting primary and intermediate inputs (including machinery items), and in turn expanding manufacturing base in the GMS. Much of the GMS final produce are manufactured using Chinese primary and intermediate inputs, which again get sold back to China. In fact, most of the trade between China-Thailand and China-Viet Nam include trade in the capital goods sector. Chinese imports are used for producing final manufactured items such as office machines, electric machines, road vehicles, and white goods, like, mobile phones, air conditioners, computers, and televisions. Most of the office machines and electrical machineries that Thailand exports, and most of the motorcycles that Viet Nam sells are made with Chinese machinery inputs. Similarly, most of the garment manufacturing units in Myanmar, Laos, and Cambodia, use Chinese textile and woven fabrics.

\section{CONCLUSION}

Our results provide evidence in support of location substitution effect hypothesis. This may be because of an increase in vertical intra-industry trade between China and the GMS countries, involving back-and-forth transaction in vertically fragmented cross-border production process. Instances, such as in the case of white goods, and garments, suggest that GMS countries are exporting finished items to China, that are increasingly getting manufactured using primary and intermediate inputs imported from China. As a result of higher cost of producing in mainland China (resulting from higher labor, land, and energy prices), and Chinese exports getting increasingly targeted by its major trading partners, Chinese firms are expanding their production base outside China. By shifting to cheaper overseas destination such as in GMS countries, Chinese firms are circumventing protectionist measures targeted against its exports. The integration with GMS comes naturally, because of closer proximity to mainland China, better policy coordination among the governments of the GMS countries, and availability of similar technology to replicate medium technology products outside mainland China.

10) For a detail analysis about direction of China-GMS trade flow see Banik (2011). 


\section{Acknowledgement}

The authors would like to thank Pradeep Srivastava, T.N. Srinivasan, and Rajeswari Sengupta, for comments on an earlier draft of this paper. The authors would also like to thanks, Mia Mikic, Ed Tower, and other participants at the WTO Research Workshop on Emerging Trade Issues in Asia and the Pacific : Meeting contemporary policy challenges, organized by UNESCAP, Thailand. The usual disclaimer applies. 


\section{REFERENCES}

Amiti, M. and C. Freund (2008). The Anatomy of China's Export Growth, World Bank Policy Research Working Paper 4628.

Anderson, J. E. and E. van Wincoop (2004). Trade Costs, Journal of Economic Literature, 42: 691-751.

Ando, M. (2006). Fragmentation and Vertical Intra-industry Trade in East Asia, North American Journal of Economics and Finance, 17: 257-281.

Arellano, M. and S. R. Bond (1991). Some Tests of Specification for Panel Data: Monte Carlo Evidence and an Application to Employment Equations, Review of Economic Studies, 58: 277-297.

Banik, N. (2011). China's New Found Love: The GMS, Journal of World Trade, 45: 1037-1057.

Blundell, R.W. and S.R. Bond (1998). Initial Conditions and Moment Restrictions in Dynamic Panel Data Models, Journal of Econometrics, 87: 115-143.

Castellani, D., F. Serit and C. Tomasi (2010). Firms in International Trade: Importers' and Exporters' Heterogeneity in Italian Manufacturing Industry, The World Economy, 33: 424-457.

Chen, M. X. and M. O. Moore (2010). Location Decision of Heterogeneous Multinational Firms, Journal of International Economics, 80: 188-199.

Chit, M. M., M. Rizov and D. Willenbockel (2010). Exchange Rate Volatility and Exports: New Empirical Evidence from Emerging East Asian Economies, The World Economy, 33: 239-263.

Côte, A. (1994). Exchange Rate Volatility and Trade, Bank of Canada Working Paper, No. 94-5, Bank of Canada, Ottawa. 
Devonshire-Ellis, C. (2011). China Now Has Third Highest Labor Cost in Emerging Asia, China Briefing, January 19.

Available on the web: http://www.china-briefing.com/news/2011/01/19/chinanear-top- of-the-list-for- wage-overheads-in-emerging-asia.html, Accessed April $21,2011$.

Fukao, K., H. Ishido and K. Ito (2003). Vertical Intra-industry Trade and Foreign Direct Investment in East Asia, Journal of the Japanese and International Economics, 17: 468-506.

Gaulier, G., F. Lemoine and D. Unal-Kesenci (2007). China's Emergence and the Reorganisation of Trade Flows in Asia, China Economic Review, 18: 209-243.

He, W. and M. A. Lyles (2008). China's Outward Foreign Direct Investment, Business Horizons, 51: 485-491.

Helpman, E. (2006). Trade, FDI and Organization of Firms, Journal of Economic Literature, 44: 589-630.

Hummels, D., J. Ishii and K. Yi. (2001). The Nature and Growth of Vertical Specialization in World Trade, Journal of International Economics, 54: 75-96.

Koopman, R., Z. Wang and S. Wei (2008). How much of Chinese Exports is Really Made in China? Assessing Domestic Value Added when Processing Trade is Pervasive, NBER Working Paper No. 14109, Cambridge, MA.

Lall, S. (1998). Export of Manufactures by Developing Countries: Emerging Patterns of Trade and Location, Oxford Review of Economic Policy, 11: 54-73.

Lall, S. (2000). The Technological Structure and Performance of Developing Country Manufactured Exports, 1985-98, Oxford Development Studies, 28: 337-369.

Levin, A., C. Lin, and C. Chu (2002). Unit Root tests in Panel Data: Asymptotic and Finite Sample Properties, Journal of Econometrics, 108: 1-24.

Leamer, E. and R. M. Stern (1970). Quantitative Empirical Economics, Boston, MA: Allyn and Bacon. 
Li, S. and J. He (2007). Excess Liquidity Control Requires a Multi-pronged Approach, China Economist, September, 1: 19-29.

Linneman, H. (1966). An Econometric Study of International Trade Flows, Amsterdam: North Holland.

Magee, S. P. (1975). Price, Income and Foreign Trade: A Survey of Recent Economic Studies, in P. B. Kenen (ed.), International Trade and Finance: Frontiers for Research, Cambridge: Cambridge University Press.

Poyhonen, P. (1963). A Tentative Model for Volume of Trade between Countries, Welwirtschaftliches Archiv, 90: 93-99.

Tenreyro, S. (2007). On the Trade Impact of Nominal Exchange Rate Volatility, Journal of Development Economics, 82: 485-508.

Tinbergen, J. (1962). Shaping the World Economy: Suggestions for an International Economic Policy, New York: Twentieth Century Fund.

Yu, X. (2007). The Pattern of Exchange Rate Effects on Chinese Prices, Review of International Economics, 14: 683-699.

Zhang, C. (2009). Excess Liquidity, Inflation and Yuan Appreciation: What can China Learn from Recent History?, The World Economy, 32: 998-1018. 


\section{APPENDIX}

\section{Commodity Classification}

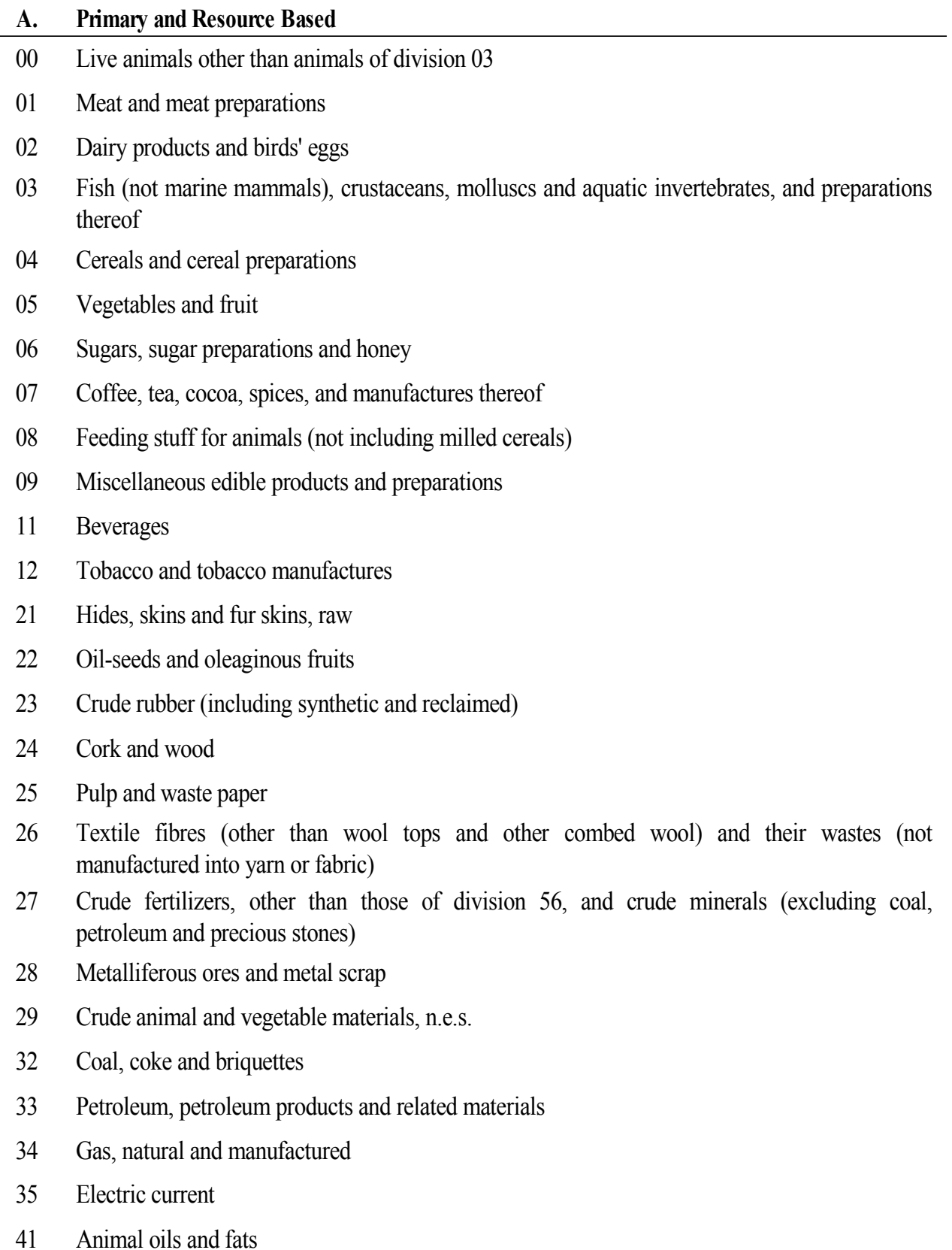


42 Fixed vegetable fats and oils, crude, refined or fractionated

43 Animal or vegetable fats and oils, processed; waxes of animal or vegetable origin; inedible mixtures or preparations of animal or vegetable fats or oils, n.e.s.

\section{B. (Industrial) Intermediate and Machinery}

51 Organic chemicals

52 Inorganic chemicals

53 Dyeing, tanning and colouring materials

54 Medicinal and pharmaceutical products

55 Essential oils and resinoids and perfume materials; toilet, polishing and cleansing preparations

56 Fertilizers (other than those of group 272)

57 Plastics in primary forms

58 Plastics in non-primary forms

59 Chemical materials and products, n.e.s.

64 Paper, paperboard and articles of paper pulp, of paper or of paperboard

65 Textile yarn, fabrics, made-up articles, n.e.s., and related products

67 Iron and steel

69 Manufactures of metals, n.e.s.

71 Power-generating machinery and equipment

72 Machinery specialized for particular industries

73 Metalworking machinery

74 General industrial machinery and equipment, n.e.s., and machine parts, n.e.s.

75 Office machines and automatic data-processing machines

76 Telecommunications and sound-recording and reproducing apparatus and equipment

77 Electrical machinery, apparatus and appliances, n.e.s., and electrical parts thereof (including non-electrical counterparts, n.e.s., of electrical household-type equipment)

78 Road vehicles (including air-cushion vehicles)

79 Other transport equipment

81 Prefabricated buildings; sanitary, plumbing, heating and lighting fixtures and fittings, n.e.s.

87 Professional, scientific and controlling instruments and apparatus, n.e.s.

89 Miscellaneous manufactured articles, n.e.s.

\section{Final Manufactured Goods}

61 Leather, leather manufactures, n.e.s., and dressed furskins

62 Rubber manufactures, n.e.s. 
63 Cork and wood manufactures (excluding furniture)

66 Non-metallic mineral manufactures, n.e.s.

68 Non-ferrous metals

82 Furniture, and parts thereof; bedding, mattresses, mattress supports, cushions and similar stuffed furnishings

83 Travel goods, handbags and similar containers

84 Articles of apparel and clothing accessories

85 Footwear

88 Photographic apparatus, equipment and supplies and optical goods, n.e.s.; watches and clocks

All SITC codes except 91, 93, 96 and 97 are included in the analysis.

Source : SITC is provided by United Nations Statistics Division, and is available at: http://unstats.un.org/unsd/cr/registry/regcst.asp?Cl=14 


\section{IMPORT DATA of GMS Countries from China(US\$)}

\begin{tabular}{|c|c|c|c|c|}
\hline & year & Primary & $\begin{array}{c}\text { Intermediate \& } \\
\text { Machinery }\end{array}$ & Final \\
\hline \multirow{10}{*}{ Laos } & 2000 & 6328186 & 2608 & 89876 \\
\hline & 2001 & 7322958 & 113602 & 21489 \\
\hline & 2002 & 9441171 & 8305 & 199885 \\
\hline & 2003 & 11022891 & 27300 & 151656 \\
\hline & 2004 & 12413597 & 64107 & 176399 \\
\hline & 2005 & 17870506 & 89126 & 7053824 \\
\hline & 2006 & 43429944 & 806755 & 5410056 \\
\hline & 2007 & 64186448 & 2751629 & 18980901 \\
\hline & 2008 & 107171726 & 2787091 & 24299944 \\
\hline & 2009 & 325771084 & 3685068 & 37863031 \\
\hline \multirow{10}{*}{ Thailand } & 2000 & 1267996345 & 2881146751 & 231642811 \\
\hline & 2001 & 1368762379 & 3081650725 & 263435038 \\
\hline & 2002 & 1388832285 & 3855563323 & 355201163 \\
\hline & 2003 & 2140223842 & 6152668228 & 533909831 \\
\hline & 2004 & 2695086328 & 8154402121 & 690932524 \\
\hline & 2005 & 2865736624 & 10419457594 & 706410949 \\
\hline & 2006 & 3880020610 & 13023224983 & 1059182417 \\
\hline & 2007 & 4615189283 & 16727859059 & 1322676370 \\
\hline & 2008 & 5683699058 & 18533337702 & 1439674840 \\
\hline & 2009 & 4830062756 & 18434634724 & 1632231888 \\
\hline \multirow{10}{*}{ VietNam } & 2000 & 859671663 & 57587810 & 11887665 \\
\hline & 2001 & 925203473 & 67918798 & 17663392 \\
\hline & 2002 & 991060697 & 95112706 & 29718341 \\
\hline & 2003 & 1192930428 & 162207431 & 101570235 \\
\hline & 2004 & 2079289800 & 228972130 & 173726732 \\
\hline & 2005 & 2095601899 & 274355999 & 182880047 \\
\hline & 2006 & 1802726365 & 409517128 & 273832807 \\
\hline & 2007 & 2238755919 & 641227901 & 346297005 \\
\hline & 2008 & 2811130823 & 1037605487 & 487581160 \\
\hline & 2009 & 2939542377 & 1329399799 & 477797616 \\
\hline
\end{tabular}




\begin{tabular}{|c|c|c|c|c|}
\hline \multirow{10}{*}{ Cambodia } & 2000 & 8329709 & 7036 & 51153972 \\
\hline & 2001 & 9431431 & 552863 & 24820014 \\
\hline & 2002 & 10168139 & 213782 & 14167814 \\
\hline & 2003 & 13615118 & 3530483 & 8855821 \\
\hline & 2004 & 14195736 & 9529994 & 6206167 \\
\hline & 2005 & 13048254 & 9317709 & 4938957 \\
\hline & 2006 & 24149729 & 7737862 & 3203764 \\
\hline & 2007 & 38783465 & 7388224 & 4894190 \\
\hline & 2008 & 26766400 & 926452 & 11135331 \\
\hline & 2009 & 24081166 & 937191 & 11873794 \\
\hline
\end{tabular}




\section{EXPORT DATA of GMS Countries to China(US\$)}

\begin{tabular}{|c|c|c|c|c|}
\hline & Year & Primary & $\begin{array}{c}\text { Intermediate \& } \\
\text { Machinery }\end{array}$ & Final \\
\hline \multirow{10}{*}{ Laos } & 2000 & 2264072 & 28930770 & 3082047 \\
\hline & 2001 & 1845695 & 49183025 & 3381201 \\
\hline & 2002 & 2054476 & 49899954 & 1867004 \\
\hline & 2003 & 1885674 & 93390053 & 2708801 \\
\hline & 2004 & 1459658 & 78652927 & 7045876 \\
\hline & 2005 & 2300694 & 95776211 & 5299563 \\
\hline & 2006 & 3397736 & 156392409 & 8348457 \\
\hline & 2007 & 3521943 & 153548325 & 7047860 \\
\hline & 2008 & 5484168 & 253665026 & 8014945 \\
\hline & 2009 & 10919649 & 321276221 & 40804119 \\
\hline \multirow{10}{*}{ Thailand } & 2000 & 339881961 & 1756864960 & 142003535 \\
\hline & 2001 & 165170107 & 2001603107 & 166154717 \\
\hline & 2002 & 226236266 & 2521923693 & 203194792 \\
\hline & 2003 & 322946311 & 3171932014 & 319551479 \\
\hline & 2004 & 370331243 & 4843170149 & 572135103 \\
\hline & 2005 & 393149296 & 6684806769 & 690810626 \\
\hline & 2006 & 441283633 & 8321635182 & 958618355 \\
\hline & 2007 & 720243146 & 10000209787 & 1310078333 \\
\hline & 2008 & 1010320267 & 12958740595 & 1666648074 \\
\hline & 2009 & 1091610523 & 10820357490 & 1394024427 \\
\hline \multirow{10}{*}{ Viet Nam } & 2000 & 304302733 & 1131914218 & 101017166 \\
\hline & 2001 & 352267603 & 1332217898 & 113289698 \\
\hline & 2002 & 598643143 & 1346751995 & 202985317 \\
\hline & 2003 & 1048893875 & 1812868842 & 320793044 \\
\hline & 2004 & 899782686 & 2944437283 & 415655446 \\
\hline & 2005 & 1257026675 & 3904406595 & 482435737 \\
\hline & 2006 & 1188581927 & 5670434711 & 595892001 \\
\hline & 2007 & 1315172040 & 9706309037 & 870797267 \\
\hline & 2008 & 1780851256 & 12088022000 & 1244849464 \\
\hline & 2009 & 2652244307 & 11788629915 & 1835508138 \\
\hline
\end{tabular}




\begin{tabular}{|c|c|c|c|c|}
\hline \multirow{10}{*}{ Cambodia } & 2000 & 9384766 & 132655884 & 22023623 \\
\hline & 2001 & 12126996 & 168755729 & 23061780 \\
\hline & 2002 & 8644767 & 215052528 & 27432217 \\
\hline & 2003 & 7222388 & 255037406 & 32354419 \\
\hline & 2004 & 29142002 & 383500205 & 39101077 \\
\hline & 2005 & 29102707 & 449301064 & 57340420 \\
\hline & 2006 & 23520721 & 597670182 & 76318354 \\
\hline & 2007 & 23908628 & 772881504 & 86428202 \\
\hline & 2008 & 40187393 & 930674927 & 121997850 \\
\hline & 2009 & 28149428 & 793198866 & 85415825 \\
\hline
\end{tabular}


